\title{
Analisis Kesalahan Siswa SMP dalam Menyelesaikan Soal Kemampuan Koneksi Matematis pada Materi Bangun Datar Segi Empat
}

\author{
Pamila Malinda ${ }^{1 *}$, Wahyu Hidayat ${ }^{2}$ \\ 1,2 IKIP Siliwangi Bandung \\ *pamilamalinda31@gmail.com
}

\begin{abstract}
ABSTRAK
Penelitian ini dilakukan untuk menganalisis kesalahan siswa dalam menyelesaikan soal kemampuan koneksi matematis pada materi bangun datar segi empat, subjek penelitian yaitu siswa kelas VIII dari salah satu SMP Negeri di Cimahi sebanyak 29 siswa. Metode yang digunakan dalam penelitian ini yaitu metode deskriptif dengan pendekatan kualita tif, instrumen yang digunakan yaitu sebanyak empat butir soal dengan kemampuan koneksi matematis siswa. Berdasarkan hasil penelitian ini dapat disimpulkan kesalahan dalam menyelesaikan soalkemampuan koneksi matematis pada materibangun datar segi empat untuk setiap indikatornya masih tinggi. Pada indikator pertama yaitu mengidentifikasi hubungan berbagai representasi konsep dan prosedur matematika pada soal nomor tiga memperoleh persentase kesalahan sebesar 63\%. Untuk indikator kedua yaitu mengidentifikasi hubungan satu prosedur ke prosedur lain dalam representasi yang ekuivalen pada soal nomor satu memperolah persentase kesalahan sebesar $24 \%$ dan soal nomor empat memperoleh persentase kesalahan sebesar $40 \%$. Dan indikator ketiga yaitu menjelaskan penera pan topik matematika da la m masalah kehidupan sehari-hari pa da soal nomor dua memperoleh persentase kesalahan sebesar $43 \%$.
\end{abstract}

Kata kunci: analisis kesalahan, kemampuan koneksi matematis, bangun datar segi empat.

\begin{abstract}
This research was conducted to analyze the students' errors in solving mathematical connection ability problems on quadrilateral, the research subjects were students of class VIII from one of State Junior High School in Cimahi with 29 students. The method used in this research is descriptive method with a qualitative approach, the instruments used are four items of students' mathematical connection ability problems. Based on the results of this study, it can be concluded that the error in solving the mathematical connection ability problem on quadrilateral for each indicator is high. In the first indicator, identifying the relationship between various mathematical concepts and procedures found in problem number three with the percentage of errors is $63 \%$. For the second indicator, identifying the relationship of one procedure to another in the equivalent representation found in problem number one obtains a percentage of error of $24 \%$ and problem number four obtains a percentage error of $40 \%$. And the third indicator that explains the application of mathematical topics in the problems of everyday life found in problem number two, with percentage of errors of $43 \%$.
\end{abstract}

Keywords: error analysis, mathematical connection ability, quadrilateral.

How to Cite: Malinda, P. \& Hidayat, W. (2020). Analisis Kesalahan Siswa SMP dalam Menyelesaikan Soal Kemampuan Koneksi Matematis pada Materi Bangun Datar Segi Empat. Journal of Medives: Journal of Mathematics Education IKIP Veteran Semarang , 4(2), 349-357. 


\section{PENDAHULUAN}

Mata pelajaran yang sangat penting untuk dipelajari yaitu salah satunya mata pelajaran matematika, Menurut (Wandini, 2019) pembelajaran matematika sendiri memuat suatu proses kegiatan guru bersama peserta didik dalam mata pelajaran matematika yang di dalamnya terkandung upaya guru untuk menciptakan suasana dan perkembangan peserta didik terhadap kemampuan, potensi, minat, bakat dan kebutuhan peserta didik tentang matematika yang sangat beragam agar terjadinya suatu interaksi yang optimal baik antar guru dengan peserta didik maupun peserta didik dengan peserta didik dalam pembelajaran matematika itu sendiri. Kemudian pembelajaran matematika siswa juga harus ditunjang dengan berbagai macam kemampuan matematis agar siswa dapat mengaplikasikan pengetahuan yang telah didapatnya dalam kehidupan sehariharinya maupun dalam bidang ilmu lain.

Salah satu kemampuan yang harus dimiliki siswa yaitu kemampuan koneksi matematis. Kemampuan koneksi mate-matis sendiri menurut Hadin et al. (2018) merupakan suatu kemampuan matematis yang menghubungkan satu topik mate-matika dengan topik matematika lain (antar topik matematika) maupun di luar matematika. kemudian (Nurafini \& Pujiastuti, 2019) menyatakan bahwa kemampuan koneksi matematis merupakan suatu keterkaitan ide-ide ataupun antar konsep matematika, matematika dengan bidang lain ataupun matematika dengan masalah kehidupan sehari-hari.
Mengenai kemampuan koneksi matematis siswa, Pitriyani et al. (2018) menyatakan bahwa dalam menjawab soal-soal kemampuan koneksi matematis, siswa masih mengalami kekeliruan dalam pengaitan konsep, dan proses pembelajaran hendaknya dapat dilakukan dengan lebih mengaitkan antar topik matematika, matematika dengan bidang ilmu lain juga matematika dengan kehidupan sehari-hari agar kemampuan koneksi matematis siswa dapat mening-kat. Selain itu menurut Sari et al. (2019) dari hasil penelitiannya bahwa rata-rata persentase kemampuan koneksi matema-tis siswa masih tergolong rendah, hal tersebut dikarenakan banyaknya terjadi kesalahan yang berkaitan dengan pengoperasian aritmatikanya sehingga prasyarat untuk materi selanjutnya sangat penting untuk dikuasi agar dapat menunjang pembelajaran selanjutnya.

Kemampuan koneksi matematis siswa yang masih tergolong rendah salah satunya pada materi bangun datar segi empat. Dari hasil penelitian (Elisahaya \& Imami, 2019) menyatakan bahwa kemampuan koneksi matematis siswa masih tergolong rendah terutama pada materi bangun datar segi empat, hal tersebut dikarenakan siswa sering mengalami kesalahan dalam menyelesaikan soal-soal yang diberikan. Berdasarkan uraian di atas maka penelitian ini bertujuan untuk menganalisis kemampuan koneksi matematis siswa pada materi bangun datar segi empat, dengan tujuan penelitian ini dapat mengetaui kesalahan-kesalahan yang dilakukan siswa dalam menyelesaikan soal kemampuan 
koneksi matematis pada materi bangun datar segi empat.

\section{METODE PENELITIAN}

Penelitian ini dilakukan untuk menganalisis kesalahan siswa dalam menyelesaikan soal kemampuan koneksi matematis pada materi bangun datar segi empat, penelitian ini merupakan penelitian desktiptif dengan pendekatan kualitatif. Subjek penelitian yaitu siswa kelas VIII dari salah satu SMP Negri di Cimahi sebanyak 29 orang siswa, instrumen yang digunkan yaitu empat butir soal kemampuan koneksi matema-tis siswa. Tahap dalam penelitian ini antara lain merencanakan kegiatan, melaksanakan kegiatan, mengumpulkan data dan menganalisis data.

Indikator kemampuan koneksi matematis yang digunakan yaitu berdasarkan indikator yang dikemukakan oleh (Sumarmo, 2015) yaitu: a) mengidentifi-kasi hubungan berbagai representasi konsep dan prosedur matematika; b) mengidentifikasi hubungan satu prose-dur ke prosedur lain dalam representasi yang ekuivalen; c) menjelaskan penerap-an topik matematika dalam masalah kehidupan sehari-hari. Pada indikator ke dua, peneliti menggunakan dua soal, dan dua indikator lainnya peneliti menggunakan masing-masing satu butir soal.

\section{HASIL DAN PEMBAHASAN}

Untuk mengetahui kesalahan siswa dalam menyelesaikan soal kemampuan koneksi matematis, digunakan empat butir soal berdasarkan indikator kemampuan koneksi matematis. Hasil tes tersebut kemudian di lihat dari hasil persentase setiap indikator dan soal yang telah diberikan kepada siswa, kemudian jawaban siswa akan dianalisis untuk melihat kesalahankesalahan yang banyak dilakukan oleh siswa dalam menyelesaikan soal kemampuan koneksi matematis pada materi bangun datar segi empat yang diberikan.

Tabel 1 memperlihatkan hasil perhitungan persentase setiap soal dari indikator kemampuan koneksi matematis yang diperoleh.

Tabel 1. Persentese Kemampuan Koneksi Matematis Tiap Indikator Soal

\begin{tabular}{|c|c|c|}
\hline $\begin{array}{l}\text { No. } \\
\text { Soal }\end{array}$ & Indikator & $\begin{array}{l}\text { Kesa- } \\
\text { lahan }\end{array}$ \\
\hline 1 & $\begin{array}{l}\text { Mengidentifikasi hubungan satu } \\
\text { prosedur ke prosedur lain dalam } \\
\text { representasi yang ekuivalen }\end{array}$ & $24 \%$ \\
\hline 2 & $\begin{array}{l}\text { Menjelaskan penerapan topik } \\
\text { matematika dalam masalah } \\
\text { kehidupan sehari-hari }\end{array}$ & $43 \%$ \\
\hline 3 & $\begin{array}{l}\text { Mengidentifikasi hubungan } \\
\text { berbagai representasi konsep dan } \\
\text { prosedur matematika }\end{array}$ & $63 \%$ \\
\hline 4 & $\begin{array}{l}\text { Mengidentifikasi hubungan satu } \\
\text { prosedur ke prosedur lain dalam } \\
\text { representasi yang ekuivalen }\end{array}$ & $40 \%$ \\
\hline
\end{tabular}

Berikut ini diambil satu jawaban siswa persoal untuk dianalisis jawabannya dilihat dari persentase setiap indikator soalnya.

\section{Soal Nomor 1}

Dengan indikator mengidentifikasi hubungan satu prosedur ke prosedur lain dalam representasi yang ekuivalen. 


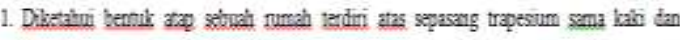
sepasang segitiga sami kaki Paca atap jang berbentik trapesim panjug sisi

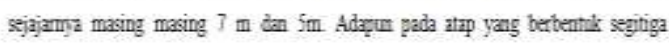

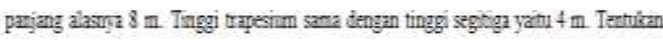

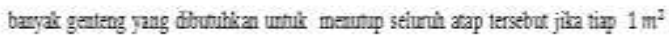

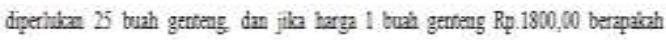

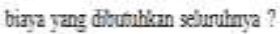

Gambar 1. Soal Nomor 1 Indikator 2

Jawaban siswa yang diambil untuk dianalisis dapat dilihat pada Gambar 2.

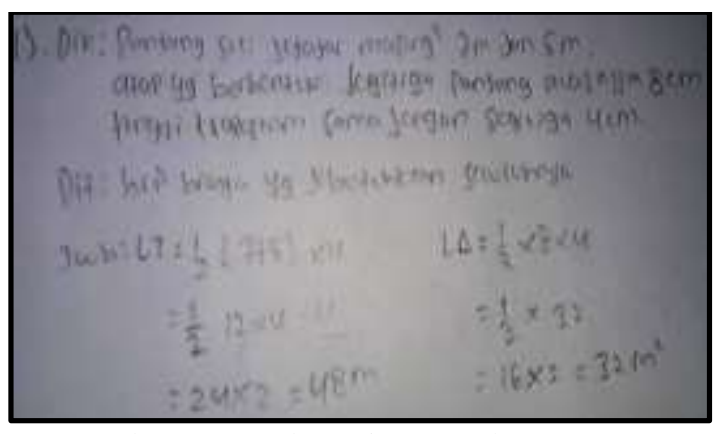

Gambar2. Jawaban Siswa Soal Nomor 1 Indikator 2

Jawaban tersebut diambil mewakili kesalahan yang banyak dilakukan oleh siswa, setelah siswa mengerjakan soal peneliti mewawancarai salah satu siswa untuk menanyakan hasil jawaban yang ditulisnya, berikut jawaban siswa yang mengalami kesulitan dalam menyelesaikannya.

Peneliti : Padajawabannya ia menuliskan apa yang diketahuinya kurang lengkap setelah, saya tanyakan kenapa?

S10 : Karna saya tidak mengerti harus dibagaimanakan genteng yang diperlukan sama harganya jadi saya engga menulisnya, diperhitungannya juga saya eng a menulisnya bu, saya hanya biasa sampai mencari luas trapesium dan segitiganya saja.

Peneliti : Kemudian saya tanya, coba sebutkan rumus luas trapesiun dan segitiga!

S10 : Sebenarnya saya lupa, Bu, dengan rumusnya.
Peneliti : Tapi dijawabannya kamu ini betul rumusnya, kenapa bisa lupa?

S10 : Karna saya lupa dengan rumusnya jadi saya nenya keteman sebelah saya bu dan dikasih tau seperti itu.

Pada hasil wawancara siswa belum bisa memahami soal yang diberikan, itu terlihat dari jawaban siswa yang menyatakan bahwa dia tidak mengerti dari apa yang diketahui yaitu jumlah genteng dalam satu meter persegi dan harga satu buah gentengnya, sehingga siswa tidak melanjutkan langkah selanjutnya untuk mencari jumlah genteng yang diperlukan juga biaya yang dibutuhkan, hal tersebut sejalan dengan yang diungkapkan oleh Hadiana et al. (2020) bahwa ketika siswa belum bisa memahami soal juga belum bisa menuangkan dalam bentuk kalimat matematika maka siswa akan kesulitan dalam menemukan solusi dari per-masalahannya. Ketika siswa ditanya mengenai rumus luas dari trapesium dan segitiga siswa ternyata lupa dengan rumus tersebut, hal tersebut terjadi akibat dari kurangnya penguasaan matematika, menurut (Marsitin, 2018) siswa mudah lupa pada konsep maupun definisi bahkan siswa dapat mengalami kesalah-an dalam menerapannya sehingga mengakibatkan penguasaan matematika yang kurang maksimal.

Pada soal nomor satu ini hanya beberapa siswa yang mengalami hal tersebut, kebanyakan siswa yang lainnya bisa menyelesaikan hanya saja ada beberapa siswa yang mengalami hal tersebut, persentase kesalahan dari soal nomor satu ini yaitu 24\%. Dari hasil wawancara hal tersebut menunjukan bahwa siswa kesulitan untuk dapat 
mengingat rumus yang harus digunakan dalam menentukan luas bangun datar Tersebut.

\section{Soal Nomor 2}

Soal Nomor 2 dengan indikator menjelaskan penerapan topik matematika dalam masalah kehidupan sehari-hari dapat dilihat pada Gambar 3 dan jawaban siswa yang diambil untuk dianalisis dapat dilihat pada Gambar 4.

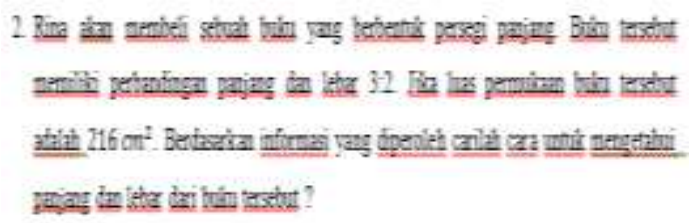

Gambar3. Soal Nomor 2 Indikator 3

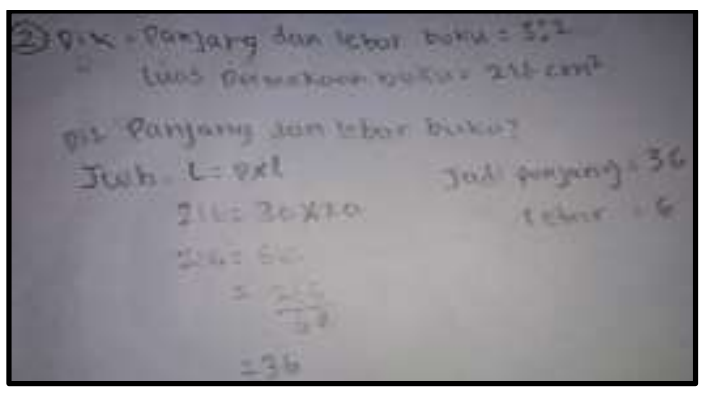

Gambar4. Jawaban Siswa Soal Nomor 2 Indikator 3

Jawaban tersebut diambil mewakili kesalahan yang banyak dilakukan oleh siswa, setelah siswa mengerjakan soal peneliti mewawancarai salah satu siswa untuk menanyakan hasil jawaban yang ditulisnya, berikut jawaban siswa yang mengalami kesulitan dalam menyelesaikannya.

Peneliti : Kamu mengerti apa yang ditanyakan dari soal tersebut?

S17 : Iya, mengerti bu. Mencari panjang dan lebar buku gambarnya.

Peneliti: Coba sebutkan rumus luas persegi panjang!

S17 : Panjang $\times$ lebar.
Peneliti : Pada jawaban kamu menulis $3 a \times$ $2 a$, kenapa kamu menulis itu?

S17 : Soalnya kan kita mau nyari panjang sama lebar, disoal ada perbandingan panjang sama lebar jadi dikaliin variabel a bu saya di situ.

Peneliti: Disini kan jawaban kamu ada $(a \times a)$ itu jadi a, terus kamu bagi 216 dengan 6a, kenapa variabel a nya jadihilang?

S17 : Karna dibagikan ya, Bu, jadi hilang a nya.

Peneliti : Kenapa kamu bisa menyimpulkan bahwa panjangnya 36 lebarnya $6 ?$

S17 : Kalo panjang sama lebar angkanya pasti besaran yang panjang jadi di situ panjangnya hasil bagi 216 dibagi 6, kalau lebarnya dari 3 dikali 2.

Peneliti : Kemu terpikir tidak kalau mencari panjang dan lebar dari soal tersebut dapat menggunakan subsitusi nilai a nantinya?

S17 : Engga, Bu, engga kepikiran ke sanah.

Dari hasil wawancara yang dilakukan bahwa siswa kesulitan untuk dapat mengoprasikan suatu variabel, sehingga pada langkah selanjutnya siswa mengalami kekeliruan dalam menjawab-nya. Dalam menyimpulkan panjang dan lebar dari persegi panjang siswa hanya menggunakan logikanya saja bahwa angka dari panjang dan lebar pasti angkanya akan besar panjang dari pada lebar. Hal tersebut memang benar akan tetapi bila dilihat dari soal siswa harus mencari terlebih dahulu nilai variabelnya baru dapat menentukan panjang dan lebar yang sebenarnya dari bangun datar tersebut. Di sini terlihat bahwa siswa dalam mengingat konsep mudah lupa, menurut Hana et al. (2019) dengan sering menyelesaikan soal kemampuan koneksi matematis siswa akan mudah dan lama dalam mengingat suatu konsep matematika, juga dalam 
penerapannya akan tepat dalam memecahkan suatu permasalahan.

Pada soal nomor dua persentase kesalahan yang diperoleh yaitu sebesar 43\%. Hal tersebut menunjukan bahwa pada soal kedua ini siswa masih belum dapat menerapkan topik matematika dalam kehidupan sehari-hari. Hal tersebut sesuai dengan hasil penelitian (Elisahaya \& Imami, 2019) bahwa pada indikator menjelaskan penerapan topik matematika dalam masalah kehidupan sehari-hari siswa masih kurang tepat dan sering mengalami kesalahan.

\section{Soal Nomor 3}

Soal Nomor 3 dengan indikator mengidentifikasi hubungan berbagai representasi konsep dan prosedur matematika dapat dilihat pada Gambar 5 dan jawaban siswa yang diambil untuk dianalisis dapat dilihat pada Gambar 6.

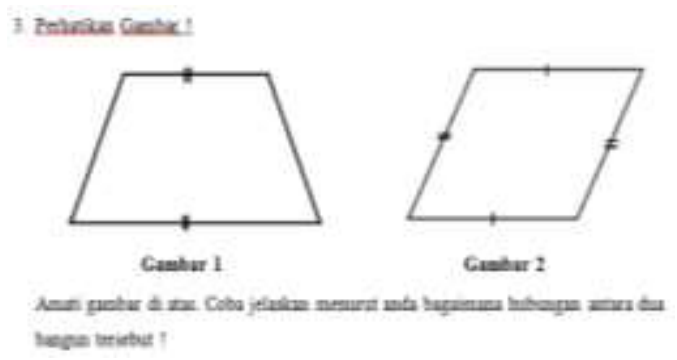

Gambar 5. Soal Nomor 3 Indikator 1

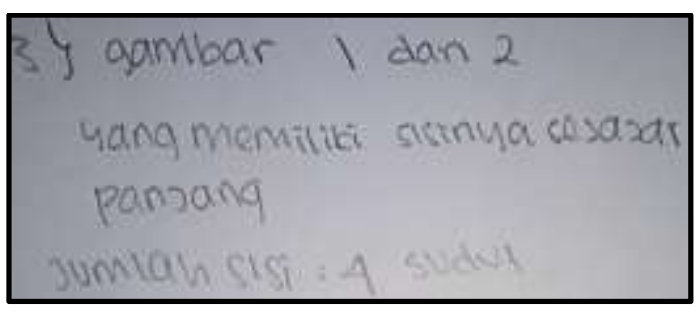

Gambar 6. Jawaban Siswa Soal Nomor 3 Indikator 1

Jawaban tersebut diambil mewakili kesalahan yang banyak dilakukan oleh siswa, setelah siswa mengerjakan soal peneliti mewawancarai salah satu siswa untuk menanyakan hasil jawaban yang ditulisnya, berikut jawaban siswa yang mengalami kesulitan dalam menyelesaikannya.

Peneliti : Кати tau bangun datar apa saja yang ada di soal nomor 3 ?

S21 : Iya bu tau, trapesium sama jajar genjang.

Peneliti : Pada jawaban kamu menuskan bahwa "yang memiliki sisinya sejajar panjang", coba jelaskan maksudnya apa?

S21 : Jadi garis yang sejajarnya tuh sama panjangnya, Bu, tidak panjang sebelah.

Peneliti : Terus kalau "jumlah sisi $=4$ sudut" maksudnya gimana?

S21 : Jadi jumlah sisinya tuh sama ada 4, terus sudutnya juga ada 4 gitu bu maksudnya.

Peneliti : Cobaada lagi engga hubungan yang lain dari kedua gambar tersebut?

S21 : Engga, Bu, engga tau lagi selain yang dua itu.

Peneliti : Apakah kamu tau hubungan daridua bangun tersebut?

S21 : Engga, Bu, saya enggatau.

Dari jawaban siswa tersebut, ia menyebutkan sifat dari kedua bangun datar pada gambar. Yang dituliskan siswa pada lembar jawaban memang kurang jelas tetapi setelah diwawancara siswa bisa menjelaskan apa yang ditulisnya, kemudian ketika ditanya hubungan dari kedua bangun tersebut siswa tidak dapat menjawab bahwa jajar genjang merupakan bentuk trapesium yang istimewa juga jajar genjang bagian dari trapesium. Di sini siswa perlu untuk mengkontruksi pengetahuan yang mere-ka miliki agar dapat menemukan sesuatu hal yang belum mereka ketahui, 
Aini et al. (2016) berpendapat bahwa proses kemampuan koneksi matematis dapat mengkonstruksi pengetahuan juga pemahaman metamatika siswa.

Persentase kesalahan pada soal nomor tiga ini yaitu sebesar $63 \%$, persentase kesalahan yang paling tinggi yaitu berada pada soal nomor tiga indikator ke satu ini. Hal tersebut menunjukkan bahwa siswa dalam mengamati sebuah bangun datar hanya melihat jumlah sisi dan sudut kemudian sisi sejajarnya. Sebetulnya ketika siswa menganalisis lebih dalam siswa akan menemukan hal-hal lain yang dapat mereka temukan sehingga dapat menyelesaikan permasalahan dengan tepat tetapi mereka tidak melakukan hal tersebut. Menurut Pujiastuti et al. (2018) dengan menganalisis suatu permasalah-an akan mempermudah siswa dalam menyelesaikannya.

\section{Soal Nomor 4}

Soal Nomor 4 dengan indikator mengidentifikasi hubungan satu prosedur ke prosedur lain dalam representasi yang ekuivalen dapat dilihat pada Gambar 7 dan jawaban siswa yang diambil untuk dianalisis dapat dilihat pada Gambar 8.

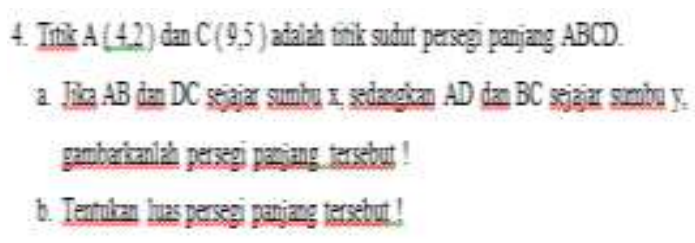

Gambar7. Soal Nomor 4 Indikator 2

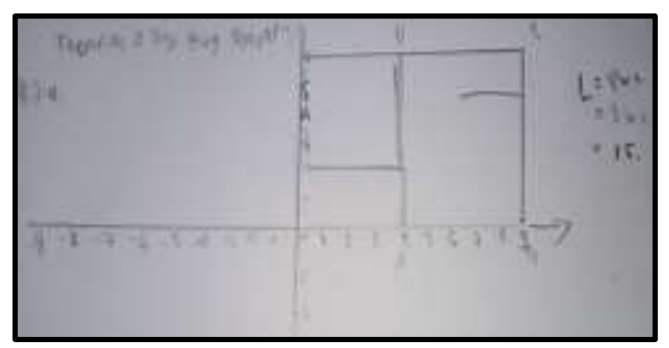

Gambar 8. Jawaban Siswa Soal Nomor 4 Indikator 2

Jawaban tersebut diambil mewakili kesalahan yang banyak dilakukan oleh siswa, setelah siswa mengerjakan soal, peneliti mewawancarai salah satu siswa untuk menanyakan hasil jawaban yang ditulisnya. Berikut jawaban siswa yang mengalami kesulitan dalam menyelesaikannya.

Peneliti : Setelah membaca soalnya, kamu mengerti apa yang ditanyakan dari soal tersebut?

S23 : Iya, Bu, ngerti nyari luas persegi panjang.

Peneliti : Dilihat dari jawaban kamu, kamu menggunakan diagram kartesius untuk menggambar persegi panjang nya, dari mana kamu tau kalau menggambarnya menggunakan diagram kartesius?

S23 : Taunya dari soalnya, Bu, kan di soal ada titik $A$, titik $C$, terus ada sumbu $x$, sumbu y jadi gambarnya pake diagram kartesius.

Peneliti : Kamu bisa menempatkan posisi titik sudut A dan titik sudut $C$ di diagram kartesius?

S23 : Bisa, Bu, cuman lupa lagi, jadi gambarnya gitu titik A nya di 4 titik $C$ nya ada di 9 sama 5.

Peneliti : Coba lihat, kamu gambar titik $C$ di $(9,5)$ tapi kenapa disumbu y setelah angka 5 ketasnyajadi 1 terus 5 ?

S23 : Itu biar pas ajah ibu di angka 5 y nya.

Peneliti : Kenapa posisi titik sudut A dan B berada tepat di sumbu $x$ ?

S23 : Saya hanya mengikuti titik A nya ajah, Bu, kalau titik B.

Peneliti: Terus kamu tau dari mana kalau panjangnya itu 5 dan lebarnya 3 ?

S23 : Kalau panjang nya taunya dari A ke B itu kan 5 yah, Bu, kalau lebarnya saya nanya temen bu katanya 3, ya udah saya kaliin ajah jadi 15. 
Dari hasil wawancara siswa mengetahui apa yang ditanyakan juga bahaimana cara menggambar persegi panjang menggunakan diagram kartesius, tetapi siswa kesulitan untuk menentukan titik sudut A, B, C, dan D sehingga ketika keempat titik sudut tersebut dihubungkan gambar persegi panjang yang siswa bentuk tidak jelas. Dalam menentukan panjang siswa sudah bisa karna pada gambar sudah betul tetapi penempatan titiknya yang salah, dan siswa tidak bisa mencari lebarnya sehingga siswa bertanya kepada temannya hal tersebut dapat dilihat dari gambar yang dibuat, ia sulit menentukan lebarnya karna pada gambar posisi titik sudut A dan D tidak tepat.

Dengan demikian siswa perlu untuk memiliki kemampuan menyelesai-kan masalah yang memiliki hubungan antar konsep matematika. Menurut (Tasni \& Susanti, 2017) kemampuan koneksi matematis dapat membantu siswa untuk dapat menyelesaikan permasalahanpermasalahan terutama permasalahan yang menghubungkan antar konsepkonsep matematika, mate-matika dengan konsep lain atau dalam kehidupan sehari-hari.

Dari hasil persentase kesalahan dari soal nomor empat ini yaitu sebesar $40 \%$, hal tersebut dikarenakan siswa kesulitan dalam prosedur penggunaan diagram kartesius sehingga siswa mengalami kesalahan dalam menempatkan keempat titik sudut dari persegi panjang tersebut, dalam mengerjakan soal nomor empat ini siswa perlu mengingat kembali pengalaman dalam mempelajari materi tersebut. Menurut (Romli, 2017) mengungkapkan bahwa kemampuan koneksi matematis sendiri terbentuk dari pengalaman-pengalaman siswa dalam belajar materi-materi yang sebelumnya telah dipelajari.

\section{PENUTUP}

Dari hasil analisis kesalahan yang telah dilakukan peneliti memperoleh bahwa kesalahan dalam menyelesaikan soal kemampuan koneksi matematis pada materi bangun datar segi empat untuk setiap inikatornya masih tinggi. Pada indikator pertama yaitu mengidentifikasi hubungan berbagai represen-tasi konsep dan prosedur matematika pada soal nomor tiga memperoleh per-sentase kesalahan sebesar $63 \%$. Untuk indikator kedua yaitu mengidentifikasi hubungan satu prosedur ke prosedur lain dalam representasi yang ekuivalen pada soal nomor satu memperolah persentase kesalahan sebesar $24 \%$ dan soal nomor empat memperoleh persentase kesalahan sebesar 40\%. Dan indikator ketiga yaitu menjelaskan penerapan topik matema-tika dalam masalah kehidupan sehari-hari pada soal nomor dua memperoleh persentase kesalahan sebesar $43 \%$.

\section{DAFTAR PUSTAKA}

Aini, K, N., Purwanto., \& Sa'dijah, C. (2016). Proses Koneksi Matematika Siswa Berkemampuan Tinggi dan Rendah dalam Memecahkan Masalah Bangun Datar. Jurnal Pendidikan, 1(3), 377-388.

Elisahaya, \& Imami, A, I. (2019). 
Analisis Kemampuan Koneksi Matematis. Prosiding Sesiomadika, 2(1), 53-61.

Hadiana, M, R., Widodo, S, A., \& Setiana, D, S. (2020). Analisis Kesalahan dalam Menyelesaikan Masalah Segi Empat Ditinjau dari Perkembangan Kognitif. Journal of Honai Math, 3(1), 1-12.

Hadin, Pauji, H, M., \& Arifin, U. (2018). Analisis Kemampuan Koneksi Matematik Siswa Mts Ditinjau Dari Self Regulated Learning. JPMI (Jurnal Pembelajaran Matematika Inovatif), 1(4), 657-666.

Hana, N., Surahmat., \& Fathani, A, F. (2019). Kemampuan Koneksi dan Pemecahan Masalah Matematis Peserta Didik Kelas VIII Melalui Model Cooperative Meaningful Instructional Design (C-MID) pada Materi Koordinat Kartesius. Jp3, 14(7), 115-122.

Marsitin, R. (2018). Koneksi Matematis dan Berpikir Kreatif dalam Pembelajaran Matematika dengan Teori APOS. Al-Khwarizmi: Jurnal Pendidikan Matematika Dan Ilmu Pengetahuan Alam, 5(1), 87-100.

Nurafini, A., \& Pujiastuti, H. (2019). Analisis Kemampuan Koneksi Matematis ditinjau dari Self Confidence Siswa: Studi Kasus Di SMKN 4 Pandeglang. ANARGYA: Jurnal Ilmiah Pendidikan Matematika, 2(1), 2833.

Pitriyani, P., Fitrianna, A, Y., Malinda, M., \& Hajar, M, S. (2018). Analisis Kemampuan Koneksi Matematik Siswa MTs Ditinjau Dari Self Confidence. Jurnal Penelitian Dan Pembelajaran Matematika, 11(1), 105-115.
Pujiastuti, E., Mulyono., \& Soedjoko, E. (2018). Pengungkapan Koneksi Matematis Sebagai Sarana Penelusuran Kemampuan dan Proses Memecahkan Masalah Peserta Didik. PRISMA, Prosiding Seminar Nasional Matematika, 1, 618-627.

Romli, M. (2017). Profil Koneksi Matematis Siswa Perempuan Sma Dengan Kemampuan Matematika Tinggi dalam Menyelesaikan Masalah Matematika. JIPMat, 1(2), 145-157.

Sari, P, C., Mutmainah, D, S., \& Setiawan, W. (2019). Analisis Kemampuan Konenksi Matematik Ditinjau dari Kemampuan Awal Matematika Siswa SMP pada Materi Persamaan Garis Lurus. Suska Journal of Mathematics Education, 5(1), 30-38.

Sumarmo, U. (2015). Berpikir dan Disposisi matematik serta Pembelajarannya. Bandung: UPI.

Tasni, N., \& Susanti, E. (2017). Membangun Koneksi Matematis Siswa dalam Pemecahan Masalah Verbal. Beta Jurnal Tadris Matematika, 10(1), 103.

Wandini, R. R. (2019). Pembelajaran Matematika untuk Calon Guru MI/SD. Medan: Widya Puspita. 